Indonesian Journal of EFL and Linguistics

Vol. 1 No. 1, 2016

eISSN: 2503-4197, pISSN: 2527-5070

www. indonesian-efl-journal.org

DOI: http://dx.doi.org/10.21462/ijefll.v1i1.2

\title{
A Comparative Study of Vocabulary Learning Strategies Employed by Iranian Undergraduate and Postgraduate EFL Learners with a Focus on Motivation
}

\author{
Dr Abdullah Sarani \\ Associate Professor, University of Sistan \& Baluchestan, Zahedan, Iran
}

Habib Shirzaei

Student in TEFL: University of Sistan \& Baluchestan

shirzaeienglish@gmail.com

\begin{abstract}
:
Vocabulary is viewed as a major part of language proficiency as it allows learners to use four language skills: listening, speaking, reading, and writing. The present study was carried out to compare Iranian undergraduate and postgraduate EFL learners' use of vocabulary learning strategies. After that the study tried to see if there was any difference between highly-motivated and low-motivated learners with regard to vocabulary use. Finally, it aimed at investigating the differences between the Iranian EFL male and female learners' use of vocabulary learning strategies. A group of 150 Iranian undergraduate and postgraduate EFL learners (75 males and 75 females) both at BA and MA levels from Zahedan universities were selected randomly. The participants' ages ranged between 18 to 42. The data were obtained through two questionnaires: Taxonomy of Vocabulary Learning Strategies developed by Schmitt (1997) and Gardner's (1985) Attitude/ Motivation Test Battery (AMTB). The findings of the study showed that there was a significant difference between undergraduate and postgraduate EFL learners' use of vocabulary learning strategies. Also, there was a difference between highly-motivated learners and lowmotivated learners' use of vocabulary learning strategies. Moreover, the results showed that the interaction between the learners' gender and motivation was
\end{abstract}


significant. The results are theoretically and pedagogically significant for EFL teachers and applied linguists.

Keywords: undergraduate, postgraduate, EFL vocabulary learning strategies, motivation

\section{INTRODUCTION}

Vocabulary learning has become the topic of interest for many EFL practitioners throughout the world. The more vocabulary an EFL learner acquires, the better communication he/she will have. In the onerous process of learning a foreign language, learning the vocabulary part of the target language has always been problematic, difficult, and bewildering to the EFL or ESL learners. Teachers and learners have always been seeking easy ways to master the vocabulary of the English language. As it is evident from the title, this study wants to investigate the vocabulary learning strategies employed by the undergraduate and postgraduate EFL learners, and it also seeks to figure out the motivation of the learners when it comes to selecting the vocabulary learning strategies. Vocabulary plays a very important role when it comes to learning a foreign language. From the late 1980s, vocabulary was an area that has drawn the researchers' interest within the domain of second language acquisition (Nation, 1997). Researchers came to understand that many of learners' difficulties, both receptive and productive, result from an insufficient vocabulary, and even when they are at high levels of language competence, they still feel in need of learning vocabulary. Wilkins (1972), describes the importance of vocabulary in his quote, "without grammar very little can be conveyed, without vocabulary nothing can be conveyed". Occasionally, all EFL learners cannot content themselves with the best way to master the vocabulary of English. They have always been in search of finding a strategy to learn, memorise, and maintain the vocabularies. Finding the vocabulary learning strategies employed by the Iranian undergraduate EFL learners on one hand, and finding the vocabulary learning strategies employed by postgraduate EFL learners on the other hand, and still one more issue is the level of the motivation of the learners in mastering vocabulary learning strategies are making the real problems of this study in which there is a need to be stated. Motivation is an essential factor that plays a major role in achieving many fundamental goals in a student's academic life (Christiana, 2009). The present study was conducted to determine what motivates Iranian undergraduate and postgraduate EFL students to study English and also to see if this motivation has an influence on their use of vocabulary learning strategies or not.

Vocabulary is regarded as "an essential part of mastering a second language" (Schmitt, 2008, p.329). Language learning strategies in general have enjoyed much popularity in recent decades in ELT. The interest in this area initiated when successful language learners became the target of the investigation of language educators and researchers. One of the attractive areas in vocabulary research has been the investigation of the strategies of vocabulary learning. In the last decades there has been an increasing interest in vocabulary learning strategies given that they 
are found to facilitate second/foreign language vocabulary learning (Alptekin, 2007; Toyoda, 2007). Research on the implementation of vocabulary strategies has revealed differences among learners in terms of their strategy use. Successful vocabulary learners were found to be active strategy users who were conscious of their learning and took steps to regulate it, whereas poor learners displayed little awareness of how to learn new words or how to connect new words to old knowledge (Atay \& Ozbulgan, 2007; Tyner, 2009). Therefore, a learner needs to be given explicit instruction to become more aware of the broad range of strategies that can be employed during the learning process (Fan, 2003; Yang, (2007).

In line with the above mentioned objectives the following research questions were raised:

1. Is there any significant difference between undergraduate and postgraduate learners' use of vocabulary learning strategies?

2. Is there any significant difference between highly-motivated undergraduate and postgraduate learners' use of vocabulary learning strategies?

3. Is there any significant difference between low-motivated undergraduate and postgraduate learners' use of vocabulary learning strategies?

4. Is there any significant difference between male undergraduate and postgraduate learners' use of vocabulary learning strategies?

5. Is there any significant difference between female undergraduate and postgraduate learners' use of vocabulary learning strategies?

\section{REVIEW OF LITERATURE}

Central to understanding students' behaviours and emotions in vocabulary learning activities, students' motivation is a necessary step toward indentifying the factors that affecting students' behaviours and emotion in vocabulary learning. Motivation is what activates behaviour and helps individuals persist in given tasks (Guthrie \& Wigfield, 2000).

Although effectiveness of vocabulary development depends in large part on meaningful vocabulary instructions (Kamil \& Hiebert, 2005), the importance of motivational variables in vocabulary learning seems to be ignored in vocabulary research. Vocabulary learning is considerably complex due to the size of the potential lexicon and the multifaceted nature of vocabulary knowledge. An attempt to understand the motivational process of vocabulary learning must be established on a recognition of the complexity of vocabulary knowledge. This recognition helps better measure the self-efficacy and attitude in specific scales of vocabulary learning. Nagy and Scott (2000) identified five aspects of vocabulary complexity: incrementality-knowing a work is not a matter of all-or-nothing, but an incremental process based on small steps; multidimensionality-word knowledge consists of multiple aspects of word knowledge such as grammar, morphology, conceptual meaning, and frequency; polysemy-words often have multiple meanings; interrelatedness - words are not isolated but interrelated with one another, for example, how well a person understand the word bread depends on part of the understanding of other words such as powder and wheat; and heterogeneity-word 
knowledge depends on words' function, for instance, knowing the word whether is quite different from understanding the word apple.

In a more recent experiment, Arjomand and Sharififar (2011) made effort to explore the relationship between vocabulary learning strategies and gender among Iranian EFL learners. They concluded that cognitive strategy was the most commonly used strategy, while social strategy was the least frequently used one. Furthermore, with respect to gender, they claimed that cognitive/ metacognitive and social strategies were respectively the most and the least commonly used ones. Considering the contradictory results of the vocabulary strategy studies, particularly at tertiary level, the results of this study may have a significant contribution to our understanding of these strategies and the way they are applied by Iranian EFL university students. Tseng and Schmitt (2008) believed that motivation should be perceived as a dynamic factor comprising a number of stages, and that each of these stages will affect in different ways the process of vocabulary acquisition, which is also dynamic.

According to Nation (2001), vocabulary learning strategies make learners enable to take more responsibility for their own learning. He maintains that a large amount of vocabulary can be acquired by using vocabulary learning strategies.

Learning vocabulary is closely related to the learners' motivation. According to (Dörnyei \& Ushioda, 2011, p.3) motivation comes from the Latin verb movere which means 'to move'; motivation is understanding what moves humans to make certain choices, to engage, to expend and to persist in action or behaviour. Given the substantial body of literature on EFL motivation, the scope of this study is limited to the motivation of Iranian undergraduate and postgraduate EFL learners as far as vocabulary learning is concerned. A large number of studies have shown a positive link between learners' achievement in FL learning and motivation. However, not many have paid attention to the difference between undergraduate and postgraduate EFL motivation in vocabulary learning strategies.

In still another study, Marin-Marin (2005) examined the utilisation of vocabulary learning strategies by 150 EFL students at the University of Quintana. It was found that guessing meaning from context, using dictionary to check the meaning and repeating silently were the most commonly used strategies and keeping notes on electric devices, using electric dictionaries, and recording words on audiotapes were the least commonly used strategies. Additionally, Marin-Marin (2005) explored that contextual guessing, dictionary use and silent repetition were utilised frequently by EFL learners at Quintana University. In contrast, electronic note keeping, using electronic dictionary and using vocabulary tape- recording were rarely used.

Griffiths (2008) edited a book, honoring Joan Rubin's pioneering work on good language learners, revealed that this group use a range of strategies for different language skill areas and purposes, depending on a range of factors, such as age, motivation, culture, and nationality. Oxford (2011) recently in her third book on L2 learning strategies offered a new theory of L2 learning strategies which addressed 
definitional and 'grain size' problems and integrated sociocultural and informationprocessing concepts.

\subsection{Motivation and Foreign Language Vocabulary Acquisition}

Even though motivation has been traditionally recognised as one of the key factors related to language learning, and one which has a paramount role in foreign language achievement by mediating the actual impact of other affective and attitudinal constructs (Gardner, 2007), very few studies have been carried out to determine the role of motivation in vocabulary learning (Kim, 2008, Gardner and MacIntyre, 1991, Laufer and Husltijn, 2001) and not even one has examined the relationship between motivation and vocabulary learning strategies. In the last decade, there has been an incremental interest in vocabulary learning strategies given that they are found to facilitate second/foreign language vocabulary learning. Relying on several vocabulary reference books and textbooks and a study involving Japanese intermediate students, Schmitt (1997) devised an extensive inventory of individual Vocabulary Learning Strategies, which contains 58 strategies. He then grouped them along two dimensions, who put learning strategies into four groups:

1- Social (SOC): using interaction with other speakers to enhance the learning process;

2- Memory (MEM): relating new material to previous knowledge;

3- Cognitive (COG): manipulation and transformation of the target language by the learner Schmitt;

4- Metacognitive (MET): being aware of, planning, monitoring and evaluating the learning process.

Most language teachers and language learners are convinced of the centrality of vocabulary. Nation (2001) believes that a large amount of vocabulary could be acquired with the help of Vocabulary Learning Strategies (VLSs) and that the strategies prove useful for students of different language levels. Among the several types of learning strategies (Cohen \& Macaro, 2007), vocabulary learning strategies have attracted the attention of many researchers around the world (Fan, 2003, Catalán, 2003; Schmitt, 1997). This is because mastering vocabulary is one of the most challenging tasks that any learner encounters while acquiring another language, and thus, learners have consistently found it necessary to compensate for their limited vocabulary (Nyikos \& Fan, 2007). This situation is especially true for EFL environments, for instance, in Iran, where exposure to English in daily life is extremely limited; as a result, vocabulary acquisition does not come naturally. Fan (2003) argues that all vocabulary learning strategies consist of five steps: (1) to encounter the words (2) to get a visual or auditory image of the word (3) to learn the meaning of the word (4) to make a strong vocabulary link between the forms and the meanings of the words and (5) to use the word.

According to Ngam (2005), "Vocabulary learning strategy organises knowledge about what learners do to find out the meaning of new words, retain them in their memory for a long time, recall them when needed in comprehension, and also apply them in language production". Ngam (2005) in an investigation revealed that 
training Thai EFL university students in using five vocabulary learning strategies (dictionary work, keyword method, semantic context, grouping and semantic mapping) enhanced their ability to learn English words and increased awareness of how to learn vocabulary. Regardless of the degree of the learner's competency in grammar and pronunciation; one cannot have efficacious communication without enough vocabulary knowledge.

\section{METHODOLOGY}

\subsection{Participants}

The participants of this study were 150 undergraduate and postgraduate Iranian EFL learners from different universities in Zahedan, Iran. After gathering the mentioned population, the questionnaires were given to the participants to answer. This group consisted of 40 female postgraduate, 40 male postgraduate, 34 female undergraduate, and 36 male undergraduate from different universities in Zahedan, aged around 18-42. The participants were selected through convenience sampling. They were all learning English as a foreign language and had no chance to learn English in an English speaking country. They were all informed about the purpose of the study and were assured that the data would be kept confidentially.

\subsection{Instruments and Materials}

The data-collection instrument used in this study were two questionnaires. One is a Taxonomy of Vocabulary Learning Strategies by Schmitt (1997) that has generally been reported to have a good internal consistency and validity. The second is Gardner's (1985) Attitude/ Motivation Test Battery (AMTB).The reliability of the first instrument was calculated through running Cronbach alpha, and the reliability index was 0.82 , which was acceptable. The reliability of the AMTB was calculated through running Cronbach alpha, and the internal consistency was 0.85 , which was acceptable.

\subsection{Data Collection Procedure}

First of all, the participants of the study were selected. Then, the researcher distributed 150 questionnaires. All 150 questionnaires were returned to the researcher. The participants were given two days to complete the questionnaires. The above-mentioned questionnaires were distributed to both male and female undergraduate and postgraduate EFL learners at both BA and MA levels. Each participant's scores on the two instruments were coded and entered into Statistical Package for the Social Sciences (SPSS).

\subsection{Data Analysis}

The data of the study were analysed through descriptive statistics (mean, SD) and inferential statistics. An Independent Samples T-Test was run to see if there is any significant difference between the vocabulary learning strategies employed by undergraduate and postgraduate EFL learners. Also, an Independent Samples T-Test was used to explore the difference between male and female undergraduate and postgraduate EFL learners. 


\section{RESULTS}

The results for the research questions are presented sequentially.

\subsection{Results for the first research question}

The first research question dealt with comparing undergraduate and postgraduate EFL learners' use of vocabulary learning strategies. The research question was restated as the following hypothesis.

Table 1: T-test for comparing BA and MA students' use of vocabulary learning strategies

\begin{tabular}{|l|l|l|l|l|l|}
\hline & Mean & SD & T & Df & P \\
\hline BA & 1.82 & 26.08 & 2.59 & 148 & 0.01 \\
\hline MA & 1.71 & 26.59 & & & \\
\hline
\end{tabular}

Based on the above table, it is found that there is a statistically significant difference between undergraduate and postgraduate EFL learners' use of vocabulary learning strategies $(\mathrm{df}=148, \mathrm{t}=2.59, \mathrm{p}=0.01<0.05)$. Therefore, the null hypothesis is rejected and it could be strongly argued that the mean of BA students outperformed that of MA students.

\subsection{Results for the Second Research Question}

The second research question dealt with comparing highly-motivated undergraduate and postgraduate EFL learners' use of vocabulary learning strategies. The results including mean and SD of the groups as well as the results of t-test are shown in the following table.

Table 2: T-test for comparing highly motivated BA and MA students' use of vocabulary learning strategies

\begin{tabular}{|l|l|l|l|l|l|}
\hline & Mean & SD & T & Df & P \\
\hline BA & 1.83 & 25.6 & 2.37 & 115 & 0.01 \\
\hline MA & 1.71 & 26.6 & & & \\
\hline
\end{tabular}

As it is shown in Table 2, there is a statistically significant difference between highly-motivated undergraduate and postgraduate EFL learners' use of vocabulary learning strategies $(\mathrm{df}=115, \mathrm{t}=37, \mathrm{p}=0.01<0.05)$.

\subsection{Results for the third research question}

This research question dealt with comparing the less motivated undergraduate and postgraduate EFL learners' use of vocabulary learning strategies. The results including mean and SD of the groups as well as the results of t-test are shown in the following table. 
Table 3: T-test for comparing low motivated BA and MA students' use of vocabulary learning strategies

\begin{tabular}{|l|l|l|l|l|l|}
\hline & Mean & SD & T & Df & P \\
\hline BA & 1.74 & 24.6 & 3.37 & 115 & 0.01 \\
\hline MA & 1.68 & 25.4 & & & \\
\hline
\end{tabular}

As it is shown in Table 3, there is a statistically significant difference between lowmotivated undergraduate and postgraduate EFL learners' use of vocabulary learning strategies $(\mathrm{df}=115, \mathrm{t}=37, \mathrm{p}=0.01<0.05)$, favoring BA students. That is, BA students' mean score on vocabulary strategies instrument outperformed that of MA students.

\subsection{Results for the fourth research question}

This research question dealt with comparing male undergraduate and postgraduate EFL learners' use of vocabulary learning strategies. The results including mean and $\mathrm{SD}$ of the groups as well as the results of t-test are shown in the following table.

Table 3: 4-T-test for comparing male BA and MA students' use of vocabulary learning strategies

\begin{tabular}{|l|l|l|l|l|l|}
\hline & Mean & SD & T & Df & P \\
\hline BA & 1.53 & 25.6 & 1.52 & 73 & 0.13 \\
\hline MA & 1.52 & 25.4 & & & \\
\hline
\end{tabular}

As it is shown in the above table, there is no statistically significant difference between male undergraduate and postgraduate EFL learners' use of vocabulary learning strategies $(\mathrm{t}=1.52, \mathrm{df}=73 ; \mathrm{p}=0.13>0.05)$.

\subsection{Results for the fifth research question}

This research question dealt with comparing female undergraduate and postgraduate EFL learners' use of vocabulary learning strategies. The results including mean and $\mathrm{SD}$ of the groups as well as the results of t-test are shown in the following table.

Table 4: T-test for comparing female BA and MA students' use of vocabulary learning strategies

\begin{tabular}{|l|l|l|l|l|l|}
\hline & Mean & SD & T & Df & P \\
\hline BA & 1.84 & 25.1 & 2.73 & 73 & 0.04 \\
\hline MA & 1.71 & 26.4 & & & \\
\hline
\end{tabular}

As it is shown in the above table, there is a statistically significant difference between female undergraduate and postgraduate EFL learners' use of vocabulary learning strategies $(\mathrm{t}=2.8, \mathrm{df}=73 ; \mathrm{p}=0.04<0.05)$, favoring female BA students.

\section{DISCUSSION}

The findings of the present study are discussed in line with the research questions. The first research question was: Is there any statistically significant difference between Iranian undergraduate and postgraduate EFL learners' use of vocabulary learning strategies? 
The finding of this study showed that there was a statistically significant difference between undergraduate and postgraduate EFL learners' use of vocabulary learning strategies. This study is in line with Soodmand Afshar et al (2004). In their study, significant differences were found in individual strategy use in 7 out of 45 strategies. EAP students' significantly frequent use of bilingual dictionaries could plausibly be explained by the fact that EAP students, because of their insufficient proficiency level, are probably not able to understand the meanings of the defining words and other related information in monolingual dictionaries and they thus make recourse to bilingual dictionaries more. On the other hand, because EFL majors have better command of English language and monolingual dictionaries provide a more detailed definition of the lexical system, they might have preferred and used monolingual dictionaries more. Furthermore, EFL learners' more frequent use of the strategy of 'checking prefixes, suffixes and word roots to discover the meaning of unknown words could be explained by hypothesising that EFL learners are probably more strategy conscious and have had more exposure to strategies and strategy training. With regard to "asking my teacher for an L1 translation" strategy, Amirian and Heshmatifar (2013) also reported 'asking my teacher for L1 translation as a social strategy was used rarely by EFL university students.

The second research hypothesis was: There is no statistically significant difference between highly-motivated undergraduate and postgraduate EFL learners' use of vocabulary learning strategies.

The results of the study showed that there was a statistically significant difference between highly-motivated undergraduate and postgraduate EFL learners' use of vocabulary learning strategies. The results verified the findings of Fitriana, et al (2011) which indicated that there is significant positive correlation between learning motivation and vocabulary mastery simultaneously and reading competence of the second grade students of SMP Negeri 4 Surakarta in the academic year 2011-2012. It means that reading competence will simultaneously follow the increase and decrease of learning motivation and vocabulary mastery. Based on the result of the study, the writer proposes that students' learning motivation should be maintained and elevated using intrinsic or extrinsic motivation, for example by giving reward, by appreciating students for doing the homework, etc. The writer also proposes that the students' vocabulary mastery should be increased.

The third research hypothesis was: There is no statistically significant difference between low-motivated undergraduate and postgraduate EFL learners' use of vocabulary learning strategies.

The results also showed that that there was a statistically significant difference between low motivated undergraduate and postgraduate EFL learners' use of vocabulary learning strategies. This finding is not in line with Chalak \& Kassaian (2010), their study indicates that $87.78 \%$ of the respondents agreed that they were highly motivated in learning a foreign language, English in this case. All respondents agreed that if they planned to stay in another English speaking country, they would try to learn their language. In another study conducted by Kitjaroonchai \& Kitjaroonchai who tried to find out if there was any significant correlation 
between the students' learning motivation (integrative and instrumental motivation) and their academic achievement shows that the correlation coefficient ( $\mathrm{r}$ ) between students' integrative motivation and their academic achievement (GPA) is $=0.293$ $(\mathrm{p}<0.001$ ), while the correlation coefficient $(\mathrm{r})$ between their instrumental motivation and their academic achievement (GPA) is $=0.218(\mathrm{p}<0.010)$. The statistical analysis suggests that there is a significant positive relation between students' learning motivation (both integrative and instrumental) and their academic achievement. This shows that both integrative and instrumental motivations are positively associated with an increase in academic achievement.

The fourth research hypothesis was: There is no statistically significant difference between male undergraduate and postgraduate EFL learners' use of vocabulary learning strategies.

It seems that the choice of VLS and gender differences has also been at the core of some researches. According to the study conducted by Khatib et al (2011), they wanted to see if there was any significant relationship between the Iranian upperintermediate EFL learners' gender and their use of VLS. An independent samples ttest was used to test the influence of gender on the learners' use of VLS. The results suggested that none of the strategy categories can be significantly $(\mathrm{p}<.05)$ related to the gender of the learners.

The fifth research hypothesis was: There is no statistically significant difference between female undergraduate and postgraduate EFL learners' use of vocabulary learning strategies.

Experimental evidence in Nyikos (1987) indicated that men outperformed women significantly with regard to visual and color association strategy for vocabulary learning. However, a close analysis of data in Catalan's study (2003) indicated females' greater use of formal rule strategies, input elicitation strategies, rehearsal strategies and planning strategies, and males' greater use of image vocabulary learning strategies. In addition, the females' total strategy usage percentages were higher than the males', which points to either different perceptions of vocabulary learning behaviours or different patterns of vocabulary strategy usage for males and females.

\section{CONCLUSION AND IMPLICATION}

As a final statement, regarding making conclusion over the study, considering the datum that this innovative study is only delimited to Iranian undergraduate and postgraduate EFL learners, the deduction is prepared as followed. The existing study was done to find out if there is any statistically significant difference between undergraduate and postgraduate EFL learners' use of vocabulary learning strategies. The difference between highly-motivated undergraduate and postgraduate EFL learners' use of vocabulary learning strategies. The difference between lowmotivated undergraduate and postgraduate EFL learners' use of vocabulary learning strategies. The difference between male undergraduate and postgraduate EFL learners' use of vocabulary learning strategies. The difference between female undergraduate and postgraduate EFL learners' use of vocabulary learning strategies. 
The findings of the study showed that there was a significant difference between undergraduate and postgraduate EFL learners' use of vocabulary learning strategies. With regard to the second research question, the result revealed that there was a significant difference between highly-motivated undergraduate and postgraduate EFL learners' use of vocabulary learning strategies. With the third question, the result indicated that there was no statistically significant difference between lowmotivated undergraduate and postgraduate EFL learners' use of vocabulary learning strategies. Considering the fourth question, the result showed that there was no statistically significant difference between male undergraduate and postgraduate EFL learners' use of vocabulary learning strategies. Regarding the fifth question, the result indicated that there was a significant difference between female undergraduate and postgraduate EFL learners' use of vocabulary learning strategies. In conclusion, vocabulary learning is a vital element in learning a second or foreign language, which affects choosing the appropriate vocabulary learning strategies and also helps the teachers to be successful in their career.

\section{REFERENCES}

Alptekin, C. (2007). Foreign Language Learning Strategy Choice: Naturalistic Versus Instructed Language Acquisition. Journal of Theory and Practice in Education, 3(1), 4-11.

Amirian, S. M. R. \& Heshmatifar, Z. (2013). The impact of using electronic dictionary on vocabulary learning and retention of Iranian EFL learners. International Journal of Research Studies in Educational Technology, 2 (1), $35-44$.

Arjomand, M., \& Sharififar, M. (2011). The most and least frequently used vocabulary learning strategies among Iranian EFL freshman students and its relationship to gender. Iranian EFL Journal, 7(1), 90-100.

Atay, D., \& Ozbulgan, C. (2007). Memory Strategy Instruction, Contextual Learning and ESP Vocabulary Recall. English for Specific Purposes, 26, 3951.

Catalán, R.M.J. (2003). Sex differences in L2 vocabulary learning strategies. International Journal of Applied Linguistics 13.1, 54-77.

Christina, O. (2009). Influence of motivation on students' academic performance. The social sciences, Medwell journals 4 (1): 30-36

Cohen A. D. \& Macaro, E. (2007), Language Learner Strategies (pp. 251-274). Oxford: Oxford University Press

Dörnyei, Z., \& Ushioda, E, (2011). Teaching and researching motivation (2nd Ed.). Harlow: Pearson Education Limited.

Fan, M. (2003). Frequency of use, perceived usefulness, and actual usefulness of second language vocabulary strategies: A study of Hong Kong learners. Modern Language Journal, 87(2), 222-241.

Indonesian Journal of EFL and Linguistics, Vol. 1 (1), 2016 
Gardner, R. C (1985), Social Psychology and Second Language Learning: The Role of Attitudes and Motivation, Edward Arnold, London.

Gardner, R. C. (2007). "Motivation and second language acquisition", Porta Linguarum 8, June: 9-20.

Gardner \& MacIntyre, (1991). 'An instrumental motivation in language study: who says it isn't effective?' Studies in Second Language Acquisition 13.

Griffiths C, (2008). Lessons from good language learners. Cambridge, UK: Cambridge University Press.

Guthrie, J.T., \& Wigfield, A. (2000). Engagement and motivation in reading. In M.L. Kamil, P.B. Mosenthal, P.D. Pearson, \& R. Barr (Eds.), Handbook of reading research: Volume III (pp. 403-422). New York: Erlbaum.

Juriah, J. (2015). Implementing Controlled Composition to Improve Vocabulary Mastery of EFL Students. Dinamika Ilmu, Vol. 15 No. 1, 2015

Kamil, M. L. \& Hiebert, E. H. (2005). Teaching and learning vocabulary: Perspectives and persistent issues. In E. H. Hiebert \& M. L. Kamil (Eds.), Teaching and learning vocabulary: Bringing research to practice (pp. 1-23). Mahwah, NJ: Lawrence Erlbaum Associates, Inc.

Khatib et.al (2011). Vocabulary learning strategies of Iranian upper-intermediate EFL learners. International Education Studies, Vol. 4, No. 2; May 2011

Kitjaroonchai, T. \& Kitjaroonchai, N (2012). Motivation toward English language learning of Thai students majoring in English at Asia-Pacific International University. Catalyst, Volume 7, No. 1,

Kim, Y. (2008). "The role of task-induced involvement and learner proficiency in L2 vocabulary acquisition", Language Learning, 58(2), 285-325.

Laufer, B. \& Hulstijn, J. (2001). "Incidental vocabulary acquisition in a second language: The construct of task induced involvement", Applied Linguistics, $22,1-26$.

Marin, M. (2005). Extraversion and the use of vocabulary learning strategies among university EFL students in Mexico (Unpublished doctoral dissertation). University of Essex, Colchester, UK.

McCarthy, M. (1990). Vocabulary. Oxford: Oxford University Press.

Nagy, W.E., \& Scott, J.A. (2000). Vocabulary processes. In M.L. Kamil, P. Mosenthal, P.D. Pearson, \& R. Barr (Eds.), Handbook of reading research. Vol. 3, pp. 269-284. Mahwah, NJ: Erlbaum.

Nation, P. (1997). The language learning benefits of extensive reading. The Language Teacher, 21(5), 13-16.

Nation, I. S. P. (2001). Learning vocabulary in another language. Cambridge, UK: Cambridge University Press. 
Ngam, T. I. (2005). The Effect of vocabulary learning strategies training on Thai university students' word retention in the second language classroom. DAI-C 662:263

Nyikos, M. (1987). The use of color and imagery as associative strategies for the retention of lexical items in German. Unpublished dissertation, Purdue University, West Lafayette, IN.

Nyikos, M. \& Fan, M. (2007). A review of vocabulary learning strategies: Focus on language proficiency and learner voice. In A. D. Cohen \& E. Macaro. (eds.), Language Learner Strategies (pp. 251-274). Oxford: Oxford University Press.

Oxford, R. (1990). Language learning strategies: What every teacher should know. Boston: Newbury House.

Oxford RL, (2011). Teaching and researching language learning strategies. Harlow, UK: Pearson Longman.

Richards, J. C. \& Renandya, W. A. (2002) Methodology in language teaching: An anthology of current practice (Cambridge: Cambridge University Press).

Schmitt, N. (1997). Vocabulary learning strategies. In N. Schmitt, \& M. McCarthy (Eds.), WoPaLP, Vol. 5, 2011 Dóczi 155 Vocabulary: Description, acquisition and pedagogy (pp.199-227). Cambridge: Cambridge University Press.

Schmitt, N. (2008). Review article: Instructed second language vocabulary learning. Language Teaching Research, 12, 329-363.

Soodmand Afshar et.al (2004). A Comparison of Iranian EAP students and EFL majors on the use of vocabulary learning strategies. International conference on current trends in ELT, 1828-1835

Toyoda, E. (2007). Enhancing Autonomous L2 Vocabulary Learning Focusing on the Development of Word-Level Processing Skills. The Reading Matrix, 7(3), 13-34.

Tseng, W.-T., \& Schmitt, N. (2008). Toward a model of motivated vocabulary learning: A structural equation modeling approach. Language Learning, 58(2), 357-400.

Tyner, B. (2009). Small-Group Reading Instruction: A Differentiated Teaching Model for Beginning and Struggling Readers. International Reading Association, Newark, DE.

Yang, M. N. (2007). Language learning strategies for junior college students in Taiwan: Investigating ethnicity and proficiency. Asian EFL Journal, 9(2), $35-57$.

Wilkins, D. (1972). Linguistics in Language Teaching, London: Edward Arnold. 